\title{
Tekstura krystalograficzna tworzyw metalicznych
}

\author{
Adam Bunsch
}

AGH Akademia Górniczo-Hutnicza, Wydział Inżynierii Metali i Informatyki Przemysłowej, Kraków

\begin{abstract}
Streszczenie: Praca przedstawia podstawowe pojęcia i zagadnienia związane $\mathrm{z}$ występowaniem zjawiska tekstury w inżynierskich materiałach polikrystalicznych. Przedstawiono definicję tekstury krystalicznej, źródła jej pochodzenia i znaczenie jej występowania. Omówiono różne metody pomiaru tekstur oraz sposoby ich opisu i przedstawiania. W pracy opisano także wpływ tekstur na własności materiałów i sposób ich wykorzystania w konkretnych wyrobach. Opracowanie jest adresowane do studentów zajmujących się zaawansowanymi metodami badań struktury materiałów oraz do wszystkich, którzy badając materiały inżynierskie, a szczególnie metale, mogą się spotkać z występowaniem w tych materiałach uprzywilejowanych orientacji krystalitów w całej ich objętości albo w pewnych ich obszarach.
\end{abstract}

Słowa kluczowe: tekstura krystalograficzna, figury biegunowe, metody badań, dyfrakcja

\section{CRYSTALLOGRAPHIC TEXTURE OF METALLIC MATERIALS}

\begin{abstract}
The work presents the basic concepts and issues related to the occurrence of the texture phenomenon in engineering polycrystalline materials. The definition of the crystalline texture, the source of its origin and the importance of its occurrence are presented. Various methods of measuring textures as well as methods of their description and presentation are discussed. The paper also presents the influence of textures on the properties of materials and the way they are used in specific products. The study is addressed to students dealing with advanced methods of researching the structure of materials and to all those who, while studying engineering materials, especially metals, may encounter the presence of privileged orientation of crystallites in these materials in their entire volume or in some regions.
\end{abstract}

Keywords: crystallographic texture, pole figures, test methods, diffraction

https://doi.org/10.7494/978-83-66727-47-2_2 


\section{Wstęp}

Tekstura krystalograficzna jest bardzo ważną cechą materiałów polikrystalicznych, gdyż decyduje o ich własnościach, a co najważniejsze - jest przyczyną anizotropii tych własności. Steksturowanie wykazuje większość tworzyw polikrystalicznych i dlatego ta ich cecha powinna być dobrze znana inżynierom materiałoznawcom zajmującym się zarówno technologiami wytwarzania materiałów, jak i ich wykorzystywaniem w konkretnych zastosowaniach (Blicharski 2002, 2004, Wierzbanowski 2019). Tekstury materiałów polikrystalicznych są od dawna opisywane w pracach naukowych (Wassermann i Grewen 1962, Karp 1968, Truszkowski i in. 1980), jednak wciąż w wielu pracach badawczych ich wpływ na własności materiałów jest często pomijany. Z tego względu wiedza na temat wpływu tekstur na własności tworzyw oraz znajomość sposobu prezentowania tekstur i ich interpretacji jest ważną umiejętnością dla inżyniera materiałoznawcy (Dobrzański 2008). Również sposoby pomiaru tekstur krystalograficznych, chociaż dość skomplikowane metodycznie i wymagające stosowania specjalistycznej aparatury, powinny być znane specjalistom z zakresu inżynierii materiałowej, aby potrafili odpowiednio planować technologie wytwarzania materiałów i prowadzić ich badania.

\section{Tekstura - pojęcie ogólne i jego różne znaczenia}

Termin „tekstura” pojawia się w wielu dziedzinach i ma wiele znaczeń. Tekstura ma swoje znaczenie dla grafików (szczególnie komputerowych), ale również dla fachowców zajmujących się opisywaniem sposobów malowania obrazów. Tekstury są przedmiotem zainteresowania geologów. Jako steksturowane określa się pokłady złóż, skał i osadów. Według polskiej wersji Wikipedii tekstura - w sensie ogólnym - oznacza cechę powierzchni przedmiotu, wrażenie, które odczuwa się za pomocą dotyku. Teksturą nazywa się też charakterystyczne dla danego materiału powtarzalne wzory na powierzchni przedmiotów, np. słoje drewna. W Wikipedii prócz definicji tekstury krystalograficznej (krystalicznej) znajdujemy również inne definicje słowa „tekstura”, wśród których wymienia się pojęcia tekstury malarskiej i graficznej, tekstury gleby i skały, a nawet tekstury muzycznej. Dla inżynierów materiałoznawców najważniejsze znaczenie ma jednak pojęcie tekstury krystalicznej (krystalograficznej). Tekstury krystalograficzne opisują i badają inżynierowie zajmujący się nowoczesnymi materiałami konstrukcyjnymi, a szczególnie inżynierowie materiałoznawcy interesujący się strukturami metali i stopów.

W prezentowanym opracowaniu interesować nas będzie tekstura jako pojęcie dotyczące własności materiału polikrystalicznego. Tekstura w tym znaczeniu jest rozumiana jako występowanie w materiale takiej sytuacji, iż krystality tworzące ten materiał względem zewnętrznego układu odniesienia mają tendencje do układania się sposób 
nieprzypadkowy, a zatem możemy mówić o występowaniu uprzywilejowanych orientacji krystalitów. Tak rozumiana tekstura jest własnością statystyczną, gdyż jej istnienie jest związane z tym, że pewne orientacje krystalitów (ziaren) ${ }^{1}$ spośród obecnych w materiale polikrystalicznym występują częściej, niżby to wynikało ze statystyki w przypadku braku jakiegokolwiek ich uporządkowania.

\subsection{Definicje tekstury}

W literaturze naukowej z obszaru inżynierii materiałowej spotykamy różne definicje tekstury krystalograficznej. Jako przykładowe definicje tekstury można podać następujące:

- Występowanie w polikrysztale nieprzypadkowego rozkładu orientacji ziarn względem zewnętrznego układu odniesienia nosi nazwę tekstury.

- Nieprzypadkowy rozkład orientacji ziarn polikryształu nazywamy teksturą.

- Materiał wykazuje teksturę, gdy orientacja bardzo licznych ziaren nie jest przypadkowa.

Dobre zrozumienie definicji tekstury wymaga zatem jednoznacznego określenia, co będziemy rozumieli przez pojęcie orientacji krystalitu (ziarna) w materiale polikrystalicznym.

\subsection{Orientacja krystalitu}

Materiał polikrystaliczny składa się z wielu (często bardzo wielu) pojedynczych krystalitów, które można w uproszczeniu utożsamiać z ziarnami. Każdy krystalit znajdujący się w tym materiale zachowuje w całej swojej objętości ciągłość kierunków i płaszczyzn krystalograficznych. Dla każdego krystalitu można określić, jak poszczególne kierunki krystalograficzne przedstawione w komórce elementarnej są zorientowane względem zewnętrznego układu odniesienia np. związanego z gotowym wyrobem, jakim jest np. płaska blacha (rys. 1a).

Sposobem przedstawiania tak określonej orientacji krystalitu jest wskazanie płaszczyzny krystalograficznej $\{\mathrm{hkl}\}$ równoległej do powierzchni wyrobu i kierunku krystalograficznego <uvw> równoległego do określonego kierunku związanego z kształtem wyrobu. Stosowany zapis $\{\mathrm{hkl}\}<\mathrm{uvw}>$ określa tak zdefiniowaną orientację pojedynczego krystalitu (ziarna) względem powierzchni i charakterystycznego kierunku w wyrobie polikrystalicznym.

\footnotetext{
1 Ziarno jest obiektem, który może być złożony nawet z kilku krystalitów. W niniejszej pracy przyjęto jednak założenie, że ziarno ma tylko jeden krystalit i używa się obu tych terminów zamiennie.
} 
a)

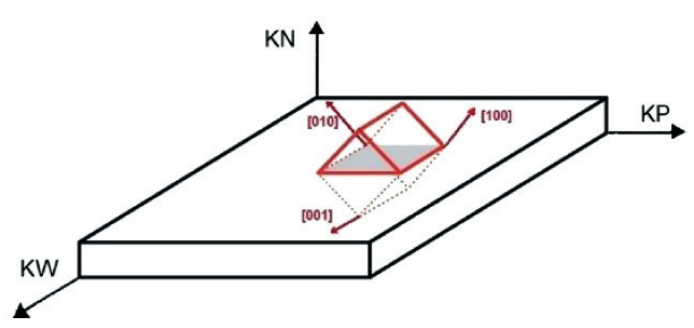

b)

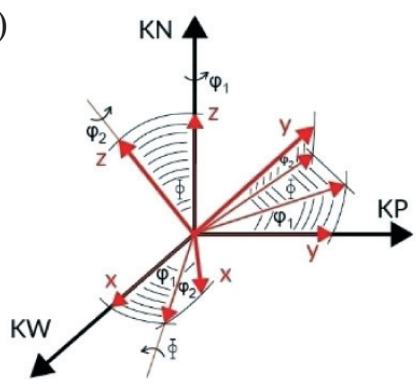

Rys. 1. Orientacja komórki elementarnej względem układu odniesienia związanego $\mathrm{z}$ wyrobem płaskim opisanym kierunkiem walcowania (KW), kierunkiem poprzecznym (KP) i kierunkiem normalnym $(\mathrm{KN})$ (a) oraz orientacja dwóch układów odniesienia opisana kątami Eulera $\varphi_{1}, \Phi, \varphi_{2}(\mathrm{~b})$

Zatem orientację krystalograficzną opisuje zestaw wskaźników: $\{$ hkl $\}<\mathbf{u v w}>$, gdzie: hkl - to wskaźniki płaszczyzny krystalograficznej równoległej do powierzchni wyrobu, a uvw - to wskaźniki kierunku krystalograficznego równoległego do wyróżnionego kierunku w wyrobie (w przypadku blach najczęściej do kierunku walcowania oznaczanego symbolem KW).

Inną formą opisywania orientacji krystalitu (ziarna) w materiale jest określanie wzajemnych orientacji dwóch układów współrzędnych: układu związanego z krystalitem oraz układu związanego z wyrobem. Taka relacja w przypadku dwóch prostokątnych układów współrzędnych jest opisywana przez trzy kąty Eulera oznaczane $\varphi_{1}, \Phi, \varphi_{2}$ (Bunge 1969, Hansen i in. 1978). Kąty te przedstawiono na rysunku 1b. W przypadku gdy rozważamy relacje pomiędzy dwoma prostokątnymi układami współrzędnych, każdy z kątów Eulera zawiera się w zakresie od $0^{\circ}$ do $90^{\circ}$. Zatem zbiór wszystkich możliwości wzajemnych relacji pomiędzy tymi dwoma układami współrzędnych zawiera się w trójwymiarowej przestrzeni kątów $\varphi_{1}, \Phi, \varphi_{2}$. Każdy z punktów tej przestrzeni kątów Eulera $\varphi_{1}, \Phi, \varphi_{2}$ określa jedną z możliwych orientacji jednego układu względem drugiego. Ten sposób opisywania wzajemnych orientacji będzie wykorzystany przy wyznaczaniu funkcji rozkładu orientacji stanowiącej jeden ze sposobów przedstawiania tekstur w materiałach polikrystalicznych.

\subsection{Orientacja idealna}

Krystality w steksturowanym materiale mają tendencje do przyjmowania określonych orientacji względem zewnętrznego układu odniesienia. Ta tendencja oznacza skupianie się orientacji pojedynczych krystalitów wokół jednej ściśle określonej orientacji, którą nazywamy orientacją idealną. Nie oznacza to, że wszystkie krystality mają tę samą orientację zgodną z idealną. W rzeczywistych steksturowanych materiałach krystality przyjmują orientacje zbliżone do idealnej, a ich rozkład wokół orientacji idealnej może mieć różny charakter (bliski, rozmyty, symetryczny, niesymetryczny). 
Orientacje idealne określa się przez podanie ściśle określonych wskaźników krystalograficznych, np. podając kierunek krystalograficzny równoległy do osi wyrobu lub jakiegoś charakterystycznego kierunku w wyrobie, a w przypadku wyrobu płaskiego podając wskaźnik płaszczyzny krystalograficznej równoległej do płaszczyzny wyrobu i kierunku równoległego do np. jego krawędzi.

\subsection{Tekstura, jako własność statystyczna}

Tekstura jest własnością statystyczną materiału polikrystalicznego. Należy zwrócić uwagę na to, że o teksturze możemy mówić tylko w odniesieniu do materiału polikrystalicznego i tylko w przypadku, gdy w tym materiale obecnych jest dostatecznie wiele pojedynczych krystalitów, tak że możemy badać rozkład ich orientacji. Skrajnym przypadkiem, w którym w materiale mamy tylko jeden krystalit, jest monokryształ. W odniesieniu do monokryształu możemy mówić jedynie o jego orientacji. Oznacza to, że możemy zmierzyć (określić), jaka płaszczyzna krystalograficzna monokryształu jest równoległa do jego powierzchni i jaki kierunek krystalograficzny jest równoległy do np. jego krawędzi. Gdy materiał składa się z dwóch, a może nawet kilku kryształów, możemy pewnymi technikami np. metoda Lauego (Cullity i Stack 2001) określić orientacje każdego z tych kryształów, ale trudno wciąż mówić o rozkładzie orientacji. W tym przypadku orientacje poszczególnych kryształów są zazwyczaj różne. Mogą być zbliżone, ale mogą się też znacznie różnić. Wciąż jednak trudno będzie mówić, że jakaś orientacja jest szczególnie uprzywilejowana. Powstaje pytanie, jaka liczba krystalitów jest graniczna i kiedy możemy zacząć badać statystykę takiego rozkładu, czyli mówić o teksturze. Przyjmuje się, że tą graniczną liczbą jest 1000 krystalitów. A zatem co najmniej tyle krystalitów musi występować w materiale lub tyle krystalitów musi być objęte pomiarem, aby dokonać pomiaru tekstury, jako własności statystycznej. Nie jest przy tym ważny rozmiar tych krystalitów. Mogą być bardzo drobne (np. o rozmiarze kilku mikronów), ale mogą być to duże krystality (nawet o rozmiarach wyrażonych w minimetrach). Ponieważ dla pomiaru tekstury istotne jest, aby pomiarem objąć co najmniej tysiąc krystalitów, istotny staje się obszar (objętość), z jakiego dokonujemy pomiaru. To może być problemem pomiarowym, gdyż w przypadku dużych krystalitów wymaga przygotowania bardzo dużych próbek i objęcia ich całej powierzchni (objętości) pomiarem lub przygotowania specjalnych próbek np. składanych z wielu przekrojów (Pańta i Chruściel 1984).

\section{Sposoby przedstawiania tekstury materiału polikrystalicznego}

Sposób przedstawiania tekstur stanowi poważny problem eksperymentalno-obliczeniowy. Wybór formy prezentowania tekstur zależy od wielu czynników, wśród których można wyróżnić kształt wyrobu, dla którego wykonywany jest pomiar, technikę 
pomiaru, a także to, jakie własności materiału są odnoszone do zmierzonych tekstur. Aktualnie do przedstawiania tekstury w pracach badawczych wykorzystujemy: figury biegunowe, odwrotne figury biegunowe, funkcje rozkładu orientacji i dwu- lub trójwymiarowe mapy orientacji (Schwarzer 2005).

\subsection{Figura biegunowa}

Figura biegunowa jest podstawową formą przedstawiania tekstury materiału polikrystalicznego (Karp 1968, Wierzbanowski 2019). Zdefiniowanie figury biegunowej wymaga przypomnienia zasad rzutu stereograficznego.

\subsubsection{Zasada rzutu stereograficznego}

Rzut stereograficzny to prezentacja kierunków krystalograficznych ${ }^{2} \mathrm{w}$ krysztale przez ich zrzutowanie na jedną z wybranych płaszczyzn tego kryształu. W przypadku gdy jest to płaszczyzna o określonych wskaźnikach, taki rzut nazywamy rzutem standardowym (Kelly i Growes 1980, Cullity i Stack 2001). Zasada rzutu standardowego jest następująca:

- Poszczególne kierunki krystalograficzne wychodzące z początku układu współrzędnych mają swoje rzuty sferyczne w miejscu, gdzie przebijają otaczającą ten układ sferę, której środek również znajduje się w początku układu współrzędnych.

- Rzuty stereograficzne poszczególnych kierunków znajdują się miejscu, gdzie płaszczyzna rzutowania (płaszczyzna równikowa sfery) przebijana jest przed proste łączące ich rzuty stereograficzne z biegunem sfery leżącym na przeciwległej półkuli względem rzutu.

Podstawową własnością rzutu stereograficznego jest zachowanie na płaszczyźnie rzutu (w przestrzeni dwuwymiarowej) zależności kątowych pomiędzy kierunkami takich, jakie występują w przestrzeni trójwymiarowej. Jest to zatem rzut izokątny, czyli zachowujący kąty pomiędzy kierunkami i płaszczyznami w krysztale.

Rzut standardowy jest graficzną dwuwymiarową prezentacją położenia poszczególnych kierunków krystalograficznych na określonej płaszczyźnie rzutowania. Każdy kierunek krystalograficzny (a w układzie regularnym równocześnie biegun płaszczyzny) jest prezentowany na rzucie jednym punktem. Na rzucie prezentuje się wiele różnych kierunków krystalograficznych o określonych wskaźnikach (np. wszystkie kierunki powstające z kombinacji wskaźników 0,1 i 2 z powtórzeniami). Taki rzut prezentuje położenia tych kierunków w jednym idealnym krysztale.

2 W układzie regularnym rzuty kierunków krystalograficznych są jednocześnie rzutami biegunów płaszczyzn krystalograficznych do nich prostopadłych. 


\subsubsection{Idealna figura biegunowa}

Idealna figura biegunowa prezentuje położenie rzutów kierunków krystalograficznych na określoną płaszczyznę np. równoległą do powierzchni wyrobu dla jednej orientacji krystalitu w tym wyrobie. Taka figura biegunowa jest szczególnym przypadkiem rzutu standardowego, na którym prezentuje się położenia rzutów tylko jednego typu kierunków określającego typ figury biegunowej.

\subsubsection{Eksperymentalna (rzeczywista) figura biegunowa}

Zachowując zasady rzutu stereograficznego, można przeprowadzić rzutowanie tylko jednego typu kierunków, np. <111>, ale nie dla jednego kryształu, lecz dla kilku, kilkunastu, kilkuset lub kilku tysięcy kryształów z wyrobu. Gdyby wszystkie kryształy miały tę samą orientację względem zewnętrznego układu odniesienia (w tym przypadku układu współrzędnych), ich rzuty leżałyby dokładnie w jednym miejscu. Jeżeli jednak każdy z kryształów ma inną orientację, ich rzuty leżą w różnych miejscach. Gdy orientacje kryształów będą zupełnie przypadkowe, rozkład rzutów kierunków na rzucie będzie również przypadkowy, czyli ich gęstość na całej powierzchni będzie jednakowa. Gdy jednak jakaś orientacja względem układu współrzędnych w pewnej grupie kryształów będzie występować częściej, objawi się to zagęszczeniem rzutów tych kierunków w określonych miejscach rzutu. Ten niejednorodny rozkład rzutów uwidoczniony na rzucie jest właśnie obrazem występowania tekstury w materiale polikrystalicznym i nazywamy go figurą biegunową (rys. 2).

Figura biegunowa jest to rozkład gęstości biegunów płaszczyzn określonego typu na powierzchni rzutu stereograficznego na płaszczyznę równoległą do powierzchni próbki. Figura biegunowa przedstawia na rzucie stereograficznym rozkład gęstości rzutów określonego typu kierunku krystalograficznego na płaszczyznę związaną z zewnętrznym układem odniesienia.

Na figurze biegunowej wykonanej dla monokryształu obserwujemy cztery bieguny \{111\} wyraźnie od siebie oddzielone (rys. 2a). Wraz ze wzrostem ilości ziaren objętych analizą następuje zmiana z pojedynczego punktu w zbiór punktów (rys. 2b), które ilościowo odpowiadają ilości analizowanych ziarn. Dla realnych próbek, w których występują miliony ziaren, przedstawienie wszystkich biegunów za pomocą punktów jest niemożliwe i zastępuje się je izoliniami łączącymi punkty o tej samej gęstości biegunów (rys. 2c).

Typowym przykładem figury biegunowej jest figura przedstawiająca teksturę wyrobu płaskiego, jakim może być na przykład blacha. W takim przypadku płaszczyzną rzutowania najczęściej jest płaszczyzna blachy. Na rysunkach $2 \mathrm{~d}-\mathrm{f}$ jako przykład przedstawiono eksperymentalne figury biegunowe walcowanego na zimno aluminium. 
a)

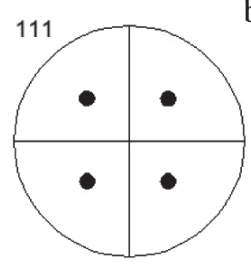

b)

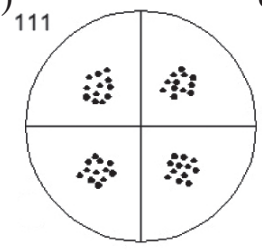

c)

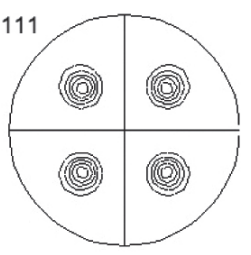

d)



e)

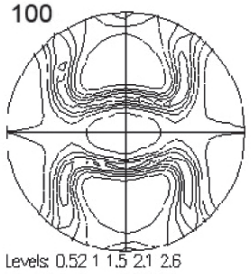

f)

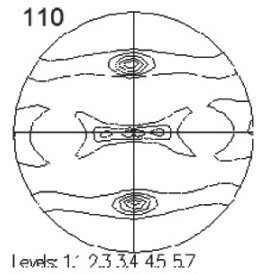

Rys. 2. Figury biegunowe przedstawiające teksturę (001)[100] dla jednego ziarna (monokryształu) (a), dwunastu ziaren (b) i realnej próbki, w której występuje wielka liczba ziaren o zbliżonej orientacji (c) oraz figury biegunowe (111) (d), (100) (e) i (110) (f) przedstawiające teksturę odkształconego na zimno aluminium Źródło: Wierzbanowski (2019)

\subsection{Odwrotne figury biegunowe}

Odwrotne figury biegunowe są to rzuty standardowe, w których pokazano położenie zewnętrznych kierunków odniesienia badanego wyrobu względem sieci krystalicznej występującej w materiale, z którego ten wyrób jest wykonany. Ten sposób prezentowania wzajemnej orientacji uzasadnia nazwę „odwrotna figura biegunowa” gdyż ten sposób prezentowana wyników jest odwrotnością zasady stosowanej przy wykreślaniu figur biegunowych. W przypadku odwrotnej figury biegunowej dokonujemy rzutowania kierunków związanych z kształtem wyrobu na płaszczyznę rzutowania związaną z kryształem, a konkretnie na płaszczyznę (001). W przypadku wyrobów walcowanych najczęściej są to położenia kierunku normalnego KN, kierunku walcowania $\mathrm{KW}$ oraz kierunku poprzecznego KP na rzucie standardowym na płaszczyznę (001). Odwrotne figury biegunowe przedstawia się w postaci rozkładów gęstości kierunków KN, KW i KP na powierzchni rzutu stereograficznego, ograniczając tę prezentację do tak zwanego trójkąta podstawowego.

Zaznaczając na trójkącie podstawowym rozkład ilości ziaren, w których orientacje zaznaczone na trójkącie są równoległe do kierunku normalnego do płaszczyzny wyrobu (blachy), otrzymujemy odwrotną figurę biegunową KN. Przykłady odwrotnych figur biegunowych KN przedstawiające tekstury cienkich warstw miedzi osadzanych elektrolitycznie pokazano na rysunku 3. 

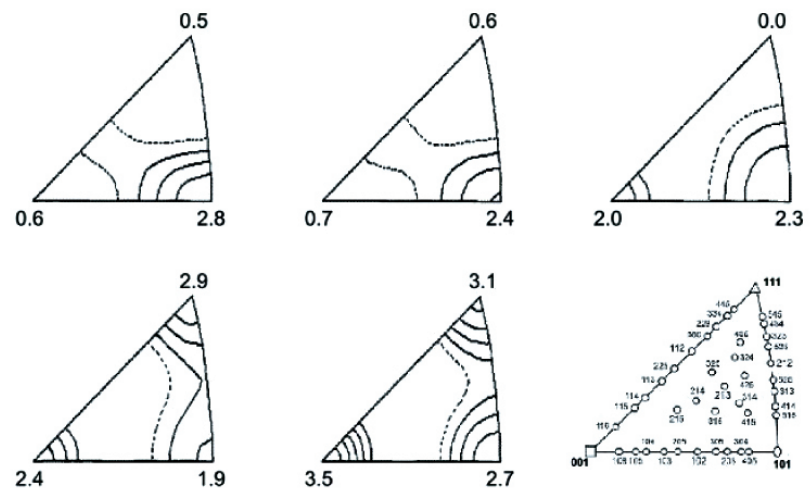

Rys. 3. Odwrotne figury biegunowe $\mathrm{KN}$ przedstawiające tekstury cienkich warstw miedzi osadzanych elektrolitycznie oraz trójkąt podstawowy, czyli fragment rzutu stereograficznego na płaszczyznę (001) z zaznaczonymi na nim orientacjami

Źródło: Skrzypek i in. (2010)

\subsection{Funkcje rozkładu orientacji - fro}

Funkcja rozkładu orientacji (fro), w języku angielskim nazywana Orientation Distribution Function (ODF), jest kolejną formą prezentowania tekstur w materiałach polikrystalicznych (Bunge 1969, Hansen i in. 1978).

Figury biegunowe wyznaczane doświadczalnie są rozkładami dwuwymiarowymi, więc nie zawierają pełnej informacji o rozkładzie orientacji krystalitów. Pełną informację zawiera trójwymiarowa funkcja tekstury zwana funkcją rozkładu orientacji $f(g)=f\left(\varphi_{1}, \Phi, \varphi_{2}\right)$. Ten zapis oznacza, że orientacja $g$ reprezentowana jest przez trzy kąty Eulera: $\varphi_{1}, \Phi, \varphi_{2}$ (por. podrozdz. 2.2).

Funkcja $f(g)$ definiowana jest następująco:

$$
\frac{d V}{V}=f(g) d g
$$

W równaniu tym $d V / V$ jest udziałem objętości krystalitów, których orientacje zawarte są w przedziale $(g, g+d g)$, czyli w niewielkim zakresie orientacji wokół tej opisanej kątami Eulera $\varphi_{1}, \Phi, \varphi_{2}$. Wartość funkcji rozkładu orientacji w danym punkcie przestrzeni kątów Eulera jest zatem udziałem objętościowym krystalitów o orientacji opisanej konkretnymi kątami $\varphi_{1}, \Phi, \varphi_{2}$. Wyznaczając te wartości w całej przestrzeni kątów Eulera, mamy pełny obraz tekstury materiału polikrystalicznego.

Funkcje rozkładu orientacji jest funkcją trójwymiarową. Dlatego też przedstawia się ją graficznie w trójwymiarowej przestrzeni kątów $\varphi_{1}, \Phi, \varphi_{2}$ jako powierzchnię o stałej wartości. Ta forma przedstawiania wyników pomiarów i obliczeń nie jest praktyczna, 
gdyż wymaga trójwymiarowych rysunków, których wygląd zależy od sposobu ich wykonania (np. przyjętej geometrii rzutu), a zatem obrazy nie są jednoznaczne i są trudne do porównywania. $\mathrm{Z}$ tego powodu najczęściej funkcje rozkładu orientacji przedstawia się w przekrojach po jednym z kątów Eulera $\left(\varphi_{1}\right.$ lub $\left.\varphi_{2}\right)$ jako linie o stałej wartości tej funkcji. W przypadku prezentowania relacji pomiędzy dwoma układami ortogonalnymi (co odpowiada np. regularnej sieci krystalograficznej materiału i geometrii wyrobu opisanej układem prostokątnym) przestrzeń funkcji rozkładu orientacji przedstawia się na kolejnych przekrojach kąta $\varphi_{1}$ lub $\varphi_{2}$ od $0^{\circ}$ do $90^{\circ}$ co $5^{\circ}$. Taki podział prowadzi do uzyskania 19 przekrojów przestrzeni fro i jest w standardowym układzie prezentowany na dwuwymiarowym rysunku (rys. 4).

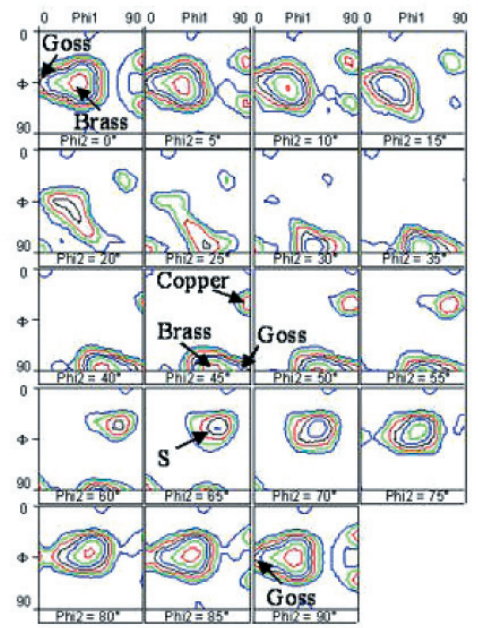

Rys. 4. Przekroje funkcji rozkładu orientacji (fro) $\varphi_{2}=$ const. przedstawiające teksturę odkształconego aluminium z zaznaczonymi charakterystycznymi składowymi tekstury

Nie ma możliwości bezpośredniego pomiaru wartości funkcji rozkładu orientacji. Danymi doświadczalnymi, które wykorzystuje się do obliczania funkcji rozkładu orientacji, są figury biegunowe. Obliczanie funkcji rozkładu orientacji jest złożonym problemem matematycznym opartym na zależnościach geometrycznych występujących w krysztale. Procedura obliczeń zależy nie tylko od posiadanych danych eksperymentalnych, ale również od typu sieci krystalicznej badanego materiału oraz geometrii (symetrii) wyrobu. Szczegóły tego typu obliczeń zostały opracowane przez matematyków (Bunge 1969, Hansen i in. 1978) i przyjęte przez materiałoznawców spotykających się na międzynarodowych konferencjach teksturowych. Funkcje rozkładu orientacji zostały również wykorzystane do rozwinięcia metod ilościowej analizy tekstur pozwalającej na określanie udziału procentowego obecnych w teksturze materiału poszczególnych jej składowych (Jura 1993). 


\subsection{Dwuwymiarowe mapy orientacji}

Wyznaczanie topografii (map) orientacji krystalograficznych jest ważną techniką badania materiałów polikrystalicznych. Wykonuje się je przy użyciu transmisyjnego mikroskopu elektronowego (TEM) lub też skaningowego mikroskopu elektronowego (SEM) (Schwarzer 1993, 2005). Mapy orientacji przedstawiają fragment próbki, na którym oznaczone są odpowiednimi kolorami krystality o tej samej orientacji (rys. 5).

a)

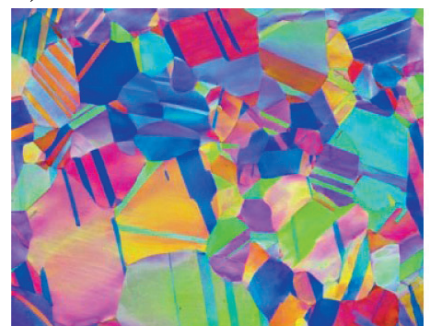

b)

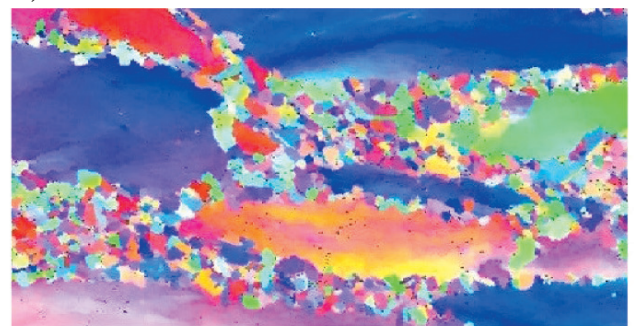

c)

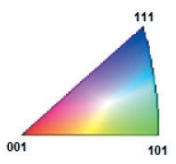

Rys. 5. Dwuwymiarowa mapa orientacji zrekrystalizowanego mosiądzu (a), dwuwymiarowa mapa orientacji częściowo zrekrystalizowanego stopu Inconel 945 (b) (Coryell i in. 2010), zasada przypisywania kolorów poszczególnym orientacjom krystalograficznym (c)

Do tworzenia map orientacji wykorzystuje się najczęściej technikę dyfrakcji elektronów wstecznie rozproszonych (EBSD) w skaningowych mikroskopach elektronowych (Juul Jensen 2000, Faryna 2012). Do tworzenia tego typu map zastosowano obrazy dyfrakcyjne Kikuchiego (TKP) oraz obrazy dyfrakcyjne uzyskane przy użyciu wiązki zbieżnej (CBED) w transmisyjnym mikroskopie elektronowym (TEM) (Schwarzer 2005). Tę technikę pomiarów nazywa się Orientation Imaging Microscopy (OIM). Obecnie oprócz map dwuwymiarowych tworzy się podobną techniką obrazy trójwymiarowe przedstawiające orientacje poszczególnych ziaren w określonej objętości materiału (Juul Jensen 2000). Tworzenia takich obrazów jest możliwe dzięki zastosowaniu przenikliwego promieniowania, np. neutronowego, i zbieraniu informacji z objętości materiału, a nie tylko jego powierzchni.

\section{Klasyfikacje tekstur krystalograficznych}

Kryteria klasyfikacji tekstur to ich pochodzenie, czyli przyczyna powstania lub proces, w którym tekstura powstaje, kształt przedmiotu (wyrobu), w którym obserwujemy teksturę, a także charakter tekstury.

\subsection{Klasyfikacja tekstur ze względu na symetrię materiału (wyrobu)}

Bardzo rzadko spotyka się niesteksturowane materiały lub wyroby, a uzyskanie takiego materiału zawsze stanowi duży problem technologiczny. Każdy wyrób (materiał) 
ma swój kształt. Ponieważ tekstura to określony i nieprzypadkowy sposób ułożenia krystalitów względem układu odniesienia związanego z wyrobem, zatem istotna jest symetria tego układu odniesienia, która określa kształt wyrobu. Ze względu na kształt wyrobu możemy wyróżnić następujące typy tekstur: teksturę wyrobu płaskiego, teksturę osiową, włóknistą i cylindryczną.

\subsubsection{Tekstury wyrobów płaskich}

Typowym przykładem wyrobów płaskich, w których występują tekstury i dla których ich istnienie ma duże znaczenie, gdyż często determinuje ich własności, są blachy walcowane. Układ odniesienia związany z blachą najczęściej określa się przez podanie trzech wzajemnie prostopadłych kierunków (walcowania KW, normalnego do powierzchni blachy KN i poprzecznego KP). Tekstura blachy (wyrobu płaskiego) jest określana przez podanie, jakie płaszczyzny krystalograficzne w poszczególnych krystalitach układają się równolegle do płaszczyzny walcowania blachy i jakie kierunki krystalograficzne układają się równolegle do kierunku walcowania. Do opisu takiej tekstury, a dokładnie - składowych tekstury wyrobu płaskiego, używa się wskaźników $\{$ hkl $\}<$ uvw $>$, gdzie hkl są to wskaźniki płaszczyzny równoległej do płaszczyzny wyrobu (płaszczyzny walcowania), a uvw są to wskaźniki kierunku równoległego do określonego kierunku w wyrobie (najczęściej kierunku walcowania).

\subsubsection{Tekstury wyrobów o symetrii osiowej}

Typowymi wyrobami o symetrii osiowej są pręty i druty. Te wyroby mają oś symetrii. Teksturę tego typu wyrobów opisuje się, podając, jakie kierunki krystalograficzne w poszczególnych krystalitach układają się równolegle lub prawie równolegle do osi wyrobu. W tych wyrobach można wyróżnić różne typy tekstur. Tekstura osiowa w tego typu wyrobie występuje wtedy, gdy określony kierunek krystalograficzny w krystalitach jest równoległy do osi wyrobu. Tekstury osiowe mogą być w tym przypadku pojedyncze, podwójne, a nawet mogą zawierać więcej składowych. Gdy tekstura jest pojedyncza, oznacza to, że w materiale w większości krystalitów określony kierunek krystalograficzny jest równoległy lub prawie równoległy do osi wyrobu. Gdy w materiale wstępują dwie grupy krystalitów (lub więcej), w których w każdej inny kierunek krystalograficzny jest równoległy do osi wyrobu, mówimy o teksturze podwójnej lub potrójnej itd.

Szczególnym przypadkiem tekstury wyrobu o symetrii osiowej jest tekstura cylindryczna. Tak określamy teksturę, w której składowa opisana jest jednym kierunkiem równoległym do osi wyrobu (tak jak w teksturze osiowej), ale dodatkowo określona płaszczyzna w krystalitach układa się równolegle do np. powierzchni wyrobu - jest to wyższy stopień uporządkowania krystalitów niż ten, który wykazuje materiał o teksturze osiowej. 


\subsection{Tekstury pojedyncze i złożone}

Jednym z kryterium klasyfikacji tekstur jest liczba składowych występujących w teksturze materiału. Na tej podstawie tekstury dzielimy na: pojedyncze, podwójne, złożone i włókniste.

Gdy w materiale tylko jedna orientacja krystalograficzna ziarn (krystalitów) jest uprzywilejowana i jej udział w przestrzeni orientacji jest wyższy niż średnia statystyczna, mówimy, że materiał wykazuje pojedynczą teksturę z jedną składową orientacją. Figury biegunowe przedstawiające takie tekstury są proste do interpretacji, gdyż można na nich wskazać położenia symetrycznie równoważnych kierunków określonego typu odpowiadającego figurze. Na tej podstawie stosunkowo łatwo można wyznaczyć wskaźniki $\{\mathrm{hkl}\}<\mathrm{uvw}>$ określające teksturę przedstawioną na figurze biegunowej. Pojedyncze tekstury są jednak rzadkim przypadkiem w realnych materiałach, w których zazwyczaj mamy do czynienia z teksturami złożonymi z kilku albo nawet wielu orientacji. W takiej sytuacji figury biegunowe są znacznie bardziej skomplikowane, a ich interpretacja nie jest łatwa.

Tekstury złożone można podzielić na różne typy w zależności od tego, jak są powiązane ze sobą składowe tych tekstur. Jednym z przypadków jest nałożenie kilku orientacji wtedy, gdy tekstura materiału złożona jest z kilku niezwiązanych ze sobą składowych. Każdej ze składowych można przypisać orientację idealną i tym samym wyróżnić ją jako składową. Wskazanie tych idealnych orientacji może nie być łatwe, ale jest możliwe do wykonania na figurach biegunowych na podstawie znajomości rzutu stereograficznego lub metodami obliczeniowymi.

Innym przypadkiem tekstury złożonej jest tekstura włóknista. W tym przypadku w teksturze materiału nie można wyróżnić pojedynczych składowych tekstury. W teksturze materiału wstępuje cały zbiór orientacji, które zmieniają się w sposób ciągły na przykład tak, że wiele płaszczyzn ze zbioru płaszczyzn należących do danego pasa krystalograficznego jest równoległych do np. powierzchni wyrobu, a równocześnie oś tego pasa jest równoległa do jakiegoś ściśle określonego kierunku układu współrzędnych związanego z wyrobem. Gdy jedna określona płaszczyzna w krystalitach wyrobu jest równoległa np. do jego powierzchni, ale nie można wyróżnić jednego kierunku krystalograficznego (leżącego na tej płaszczyźnie) jako równoległego do układu odniesienia związanego z wyrobem, mamy w materiale teksturę osiową - wtedy też kierunek krystalograficzny prostopadły do tej płaszczyzny jest prostopadły do powierzchni wyrobu i stanowi niejako oś, wokół której są obrócone płaszczyzny o tych samych wskaźnikach.

\subsection{Klasyfikacje tekstur ze względu na przyczyny powstawania}

Ważnym kryterium klasyfikacji tekstur jest przyczyna ich powstawania. Na tej podstawie wyróżniamy tekstury pierwotne, do których zaliczamy tekstury: osadzania, 
krystalizacji, odkształcenia, oraz tekstury wtórne, do których zaliczamy tekstury: wyżarzania, rekrystalizacji, rozrostu ziarna oraz przemiany fazowej.

Tekstury osadzania występują w cienkich warstwach metalicznych otrzymanych przez osadzanie z pary lub cieczy. Tekstury krystalizacji powstają podczas krystalizacji z fazy ciekłej. Tekstury odkształcenia powstają na skutek mechanicznego odkształcenia materiału (deformacji). Tekstury wyżarzania-rekrystalizacji tworzą się podczas wyżarzania materiału, jak również rekrystalizacji i rozrostu ziarna. Tekstury przemiany fazowej powstają w materiale po przemianie fazowej z fazy wyjściowej (która również może być teksturowana i najczęściej jest steksturowana).

\subsubsection{Tekstury osadzania}

Cienkie warstwy metaliczne otrzymuje się często przez osadzanie z pary lub cieczy. Ich orientacje krystalograficzne zależą od natury substratów oraz warunków symetrii procesu osadzania. Najczęściej warstwy osadzane mają teksturę włóknistą o osiach równoległych do kierunku wzrostu warstwy, czyli o określonym kierunku krystalograficznym prostopadłym do powierzchni osadzania. Często jest tak, że tekstura warstwy osadzanej doskonali się w miarę jej nakładania (wzrostu).

\subsubsection{Tekstury krystalizacji}

Prawie wszystkie metale i stopy zanim przybiorą ostateczną formę przewidziana do dalszej obróbki lub wykorzystania w praktyce, przechodzą przez stan ciekły izotropowy. W czasie krystalizacji ze stanu ciekłego zachodzą procesy nadające powstającym ziarnom pewne określone orientacje krystalograficzne, które wpływają na własności materiału.

Krzepnięcie zazwyczaj zaczyna się w miejscu kontaktu cieczy z wlewnicą. Liczne ziarna zarodkujące na zimnej ścianie mają najczęściej przypadkowe orientacje krystalograficzne. Spośród tych ziaren w czasie krzepnięcia odlewu niektóre rozrastają się w głąb krystalizującej cieczy szybciej niż inne, tworząc tak zwaną strefę kryształów słupkowych (kolumnowych) o wyraźnie określonej orientacji krystalograficznej. Ta strefa odlewu ma wyraźnie określoną teksturę, która wpływa istotnie na tekstury występujące w wyrobach powstających po jego przeróbce. Przykładem procesu, w którym tworzą się tekstury krzepnięcia, jest proces krystalizacji wlewka stalowego. W procesie tym obserwuje się powstawanie strefy kryształów zamrożonych o bezładnej orientacji ziaren oraz strefy kryształów kolumnowych o wyraźnej teksturze. Ich powstawanie wynika $\mathrm{z}$ istnienia kierunków krystalograficznych, które są uprzywilejowanymi kierunkami wzrostu kryształów podczas krzepnięcia. W przypadku krzepnięcia metalu zachodzącego w obecności jakiegoś ukierunkowanego zjawiska fizycznego, na przykład pola magnetycznego, działającej siły odśrodkowej lub bardziej skomplikowanych warunków chłodzenia, mogą powstawać różne i bardziej wyraźne tekstury, np. tekstury włókniste. 


\subsubsection{Tekstury odkształcenia}

Procesy przeróbki plastycznej - zarówno te prowadzone na gorąco, jak i na zimno powodują pojawienie się w materiałach tekstur zwanych teksturami odkształcenia. Tekstury odkształcenia powstają na skutek obrotu ziaren w wyniku procesu odkształcenia (walcowanie, przeciaganie, kucie i inne). W efekcie w odkształcanym materiale polikrystalicznym określony kierunek krystalograficzny jest równoległy do osi (w przypadku wyrobów o kształcie osiowym - np. drut, pręt) lub w przypadku wyrobów płaskich (np. blach) określona płaszczyzna krystalograficzna jest równoległa do powierzchni wyrobu, a kierunek równoległy do kierunku jego walcowania. Jako przykład można wskazać metale o strukturze krystalicznej A1, w których w zależności od ich energii błędu ułożenia w czasie walcowania tworzą się charakterystyczne tekstury odkształcenia, zwane teksturą typu metalu lub typu stopu (Ratuszek 1995, Blicharski 2002).

\subsubsection{Tekstury wyżarzania i rekrystalizacji}

W czasie wyżarzania wcześniej odkształconego materiału najczęściej następuje zmiana tekstury materiału z tekstury odkształcenia na teksturę wyżarzania (rekrystalizacji), a tylko czasem materiał zrekrystalizowany zachowuje teksturę materiału odkształconego. Przemiana tekstury odkształcenia w teksturę wyżarzania jest uzależniona od stopnia wyżarzenia materiału (Bunsch i Juul Jensen 1992, Ratuszek 1995). Zdrowienie zasadniczo nie powoduje zmiany tekstury materiału. Dopiero proces rekrystalizacji przebiegający na drodze zarodkowania i wzrostu prowadzi do jej zmiany. Przebieg tej zmiany opisują dwie teorie tworzenia się tekstur rekrystalizacji: teoria zorientowanego zarodkowania i teoria uprzywilejowanego wzrostu.

Teoria zorientowanego zarodkowania przyjmuje, że w odkształconym materiale w czasie jego rekrystalizacji powstają zarodki nowych ziaren wyłącznie o określonych orientacjach krystalograficznych względem odkształconej osnowy. Te zarodki w procesie wzrostu zajmują całą objętość materiału, a zatem ich orientacja decyduje o teksturze zrekrystalizowanego materiału. Teoria uprzywilejowanego wzrostu przyjmuje, że powstające zarodki mają wszystkie możliwe orientacje krystalograficzne, jednak ich prędkość wzrostu w głąb odkształconej osnowy zależy od tych orientacji i jest różna, a zatem tekstura zrekrystalizowanego materiału jest zdeterminowana orientacją tych zarodków, które względem odkształconej osnowy rosną najszybciej.

Jeżeli materiał jest poddawany dłuższemu wyżarzaniu, może dojść do procesu rozrostu ziaren polegającego na wzroście ziaren dużych kosztem tych mniejszych. Ten proces prowadzi najczęściej do wzmocnienia tekstury materiału, jednak ze względu na olbrzymi rozmiar powstających ziaren zaczynamy mieć w tym przypadku do czynienia bardziej z zagadnieniem orientacji pojedynczych ziaren niż teksturą, która jest własnością statystyczną i opisuje duże populacje ziaren. 


\subsubsection{Tekstury przemiany fazowej}

Mianem tekstury przemiany fazowej określa się teksturę w materiale po przemianie fazowej. Tekstura przemiany fazowej obecna w materiale po przemianie fazowej zależy od tekstury fazy wyjściowej, a także ewentualnej relacji krystalograficznej, jaka może łączyć orientacje komórek elementarnych fazy wyjściowej i fazy powstającej $\mathrm{w}$ trakcie przemiany. W przypadku np. przemiany $\alpha \mathrm{w} \gamma \mathrm{w}$ stalach istnieją takie relacje pomiędzy komórkami austenitu i martenzytu, spośród których najbardziej znana jest relacja Kurdjumowa-Sachsa oraz Baina (Blicharski 2004).

\subsection{Niejednorodność tekstur}

W najprostszym przypadku materiał ma jednakową teksturę w całej objętości. Mówimy wtedy o jednorodnej teksturze materiału. Częściej jednak mamy do czynienia z przypadkami, gdy tekstura materiału jest niejednorodna, czyli niejednakowa w całej objętości (Truszkowski i in. 1980, Major 1987, Bonarski 2001). Charakter tej niejednorodności najczęściej zależy od kształtu przedmiotu (wyrobu) i technologii jego produkcji. Różnice możemy obserwować w teksturze warstw powierzchniowych wyrobu i jego warstw wewnętrznych. Mówimy wtedy o teksturze powierzchni i teksturze warstw wewnętrznych. Różnice w teksturze można obserwować również w poszczególnych miejscach wyrobów (np. środek pasma walcowanego i jego krawędź lub początek i koniec wyrobu). Każdy taki przypadek wymaga takiego zaplanowania sposobu pomiaru tekstury, aby ta niejednorodność mogła zostać zdiagnozowana. Dopiero po stwierdzeniu, że tekstura w każdym miejscu wyrobu jest jednakowa, pojedynczy pomiar może być podstawą do wnioskowania o teksturze całego wyrobu.

\section{Metody pomiaru tekstury krystalicznej}

Istnieją metody oznaczania pojedynczych orientacji monokryształów. Do takich metod należy znana krystalografom metoda Lauego (Cullity i Stack 2001). Ponieważ każdy krystalit w materiale polikrystalicznym może być traktowany jako monokryształ, zatem jeżeli wielkość pojedynczego ziarna (krystalitu) w materiale polikrystalicznym jest dostatecznie duża dla stosowanej techniki pomiarowej, jest możliwość określenia orientacji takiego ziarna. Pomiar tekstury wymaga jednak określania orientacji bardzo wielu krystalitów w aglomeracie polikrystalicznym. Powstaje więc pytanie, czy taki pomiar orientacji ziarno po ziarnie w przypadku dużej ilości ziaren jest możliwy. Dla takiego sposobu pomiaru tekstury istnieją co najmniej dwie bariery techniczne. Często pojedyncze krystality są tak małych rozmiarów, że nie ma technicznej możliwości pomiaru ich orientacji wspomnianymi metodami. Ponieważ pomiar pojedynczej orientacji jest procesem złożonym, zatem niezmiernie czasochłonne byłoby oznaczenie tą metodą 
orientacji dostatecznej liczby krystalitów - tak dużej, aby móc badać ich statystyczny rozkład. Pewne możliwości w tym względzie dają współczesne metody mikroskopii elektronowej i skaningowej wsparte technologiami komputerowymi i informatycznymi.

Pomiar tekstury jako własności statystycznej materiału umożliwiają metody dyfrakcji promieniowania rentgenowskiego lub neutronowego. Są to metody pośrednie pomiaru, gdyż nie polegają na bezpośrednim pomiarze orientacji krystalitów, ale opierają się na pomiarze efektu dyfrakcyjnego, który od tej orientacji zależy. Pomiary te polegają na określaniu intensywności promieniowania ugiętego na określonych płaszczyznach krystalograficznych w krystalitach materiału polikrystalicznego.

\subsection{Ocena steksturowania materiału na podstawie zdjęcia rentgenowskiego}

Oceny, czy materiał jest steksturowany, można dokonać rentgenowskimi metodami fotograficznymi (Cullity i Strack 2001) bez angażowania skomplikowanej aparatury. Na zdjęciu rentgenowskim materiału polikrystalicznego wykonanym w płaskiej kamerze techniką promieni zwrotnych obserwujemy (w przypadku dostatecznie drobnej struktury) koncentryczne pierścienie Debye’a pochodzące od określonych płaszczyzn krystalograficznych, dla których są spełnione warunki dyfrakcji. Jeżeli materiał nie jest steksturowany, pierścienie Debye’a na całym obwodzie mają jednakową intensywność (czyli stopień zaczernienia kliszy fotograficznej jest jednakowy na całym pierścieniu). Gdy materiał jest steksturowany, zaczernienie pierścieni zmienia się na obwodzie (rys. 6). Taki charakter pierścieni wskazuje na wstępowanie tekstury w materiale. Na podstawie położenia zaczernień na obwodzie pierścienia można za pomocą analizy geometrycznej określić typ tej tekstury (Bojarski i Łągiewka 1988).

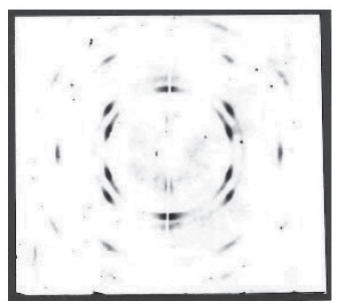

Rys. 6. Zdjęcie rentgenowskie wykonane w płaskiej kamerze metodą promieni przechodzących, przedstawiające steksturowanie pręta $\mathrm{z}$ aluminium

\subsection{Ocena stopnia steksturowania materiału na podstawie zapisu dyfraktometrycznego - indeksy teksturowe}

Zapis dyfraktometryczny metodą Bragga-Brentano pozwala jednoznacznie określić, czy materiał jest steksturowany przez analizę wartości współczynników będących stosunkami intensywności np. par linii dyfrakcyjnych $\mathrm{I}_{111} / \mathrm{I}_{200}, \mathrm{I}_{110} / \mathrm{I}_{200}$ (Bojarski i Łąiewka 1988). Wartości tych współczynników dla materiałów niesteksturowanych (bez tekstury) można obliczyć z danych tablicowych zawartych w międzynarodowych standardach 
dyfrakcyjnych w kartach ICDD. Wzorcowe zapisy dyfrakcyjne podane w tej bazie danych są zapisami dla materiałów jednofazowych bez tekstury. Zatem gdy stosunek intensywności dwóch linii dyfrakcyjnych dla zapisu eksperymentalnego różni się od tego stosunku dla wzorca, oznacza to, że materiał jest steksturowany. Im większa jest ta różnica, tym bardziej materiał jest steksturowany.

W praktyce stosuje się różne wskaźniki steksturowania obliczane na podstawie zapisów dyfrakcyjnych metodą Bragga-Brentano. Mogą to być, jak wspomniano wcześniej, stosunki intensywności dwóch wybranych linii dyfrakcyjnych, ale używa się też bardziej skomplikowanych współczynników, zawsze jednak zasada jest ta sama: indeks dla realnego materiału porównujemy z indeksem obliczonym dla niesteksturowanego wzorca. Różnica pomiędzy wartościami indeksów wskazuje na stopień steksturowania.

Przykładem takiego indeksu tekturowego jest wskaźnik orientacji określony wzorem:

$$
\mathrm{M}_{\mathrm{hkl}}=\left\{\mathrm{I}_{(\mathrm{hkl})} /\left(\mathrm{I}_{(110)}+\mathrm{I}_{(200)}+\ldots\right)\right\} /\left\{\mathrm{IF}_{(\mathrm{hkl})} /\left(\mathrm{IF}_{(110)}+\mathrm{IF}_{(200)}+\ldots\right)\right\}
$$

gdzie:

$\mathrm{I}_{(\mathrm{hkl})}$ - zmierzona intensywność linii dyfrakcyjnej hkl,

$\mathrm{IF}_{(\mathrm{hkl})}$ - intensywność linii dyfrakcyjnej hkl odczytana z wzorca ICDD.

Wartość równa 1 tak zdefiniowanego wskaźnika oznacza brak tekstury w materiale. Wartości mniejsze od jedności lub wyższe od jedności wskazują na steksturowanie materiału. Tak zdefiniowane wskaźniki mogą być wykorzystane w wielu sytuacjach, gdy istotna jest ocena, czy materiał jest steksturowany, lub gdy wystarczające jest porównanie stopnia steksturowania materiałów albo tylko bieżąca ocena stopnia steksturowania, np. bezpośrednio na linii produkcyjnej wyrobów walcowanych lub w laboratoriach, które nie dysponują dyfraktometrem z przystawką teksturową niezbędną do pełnego pomiaru tekstury.

\subsection{Pomiar tekstury rentgenowską metodą dyfraktometryczną}

Dla pojedynczego kryształu prawo Bragga określa warunki ugięcia promieniowania na określonej rodzinie płaszczyzn krystalograficznych. Przy zastosowaniu promieniowania o określonej długości fali to ugięcie zachodzi, gdy spełnione jest równanie:

$$
n \lambda=2 d_{h k l} \sin \Theta
$$

gdzie:

$n$ - rząd odbicia (liczba całkowita),

$\lambda$ - długość fali,

$d_{h k l}$ - odległość między płaszczyznami o wskaźnikach hkl,

$\Theta$ - kąt padania promieniowania na kryształ.

Gdy promieniowanie rentgenowskie pada pod określonym kątem na bardzo liczny zbiór różnie zorientowanych $\mathrm{w}$ przestrzeni krystalitów, tylko nieliczne $\mathrm{z}$ nich będą tak zorientowane względem wiązki padającej, że prawo Bragga będzie spełnione. Jeżeli przyjmiemy w odpowiednio zaprojektowanym urządzeniu taką strategię pomiaru, że na 
określoną powierzchnię lub na określoną objętość materiału polikrystalicznego będzie padać pod zmieniającymi się odpowiednio kątami promieniowanie rentgenowskie lub neutronowe, pomiar tekstury (figury biegunowej) stanie się możliwy. Każdej orientacji badanego przedmiotu względem promieniowania padającego możemy przypisać zmierzoną eksperymentalnie intensywność promieniowania ugiętego. Ta intensywność jest proporcjonalna do ilości krystalitów, które w tym położeniu miały taką orientację, że spełnione było prawo Bragga. Gdy przeprowadzimy taki pomiar dla wybranego fragmentu przestrzeni orientacji preparatu względem wiązki padającej, uzyskamy informacje o rozkładzie gęstości poszczególnych orientacji krystalitów w tym zakresie przestrzeni.

Aby uzyskać eksperymentalny obraz figury biegunowej, musimy dla każdej orientacji odpowiadającej poszczególnym położeniom na siatce biegunowej wykonać pomiar intensywności odbicia promieniowania (rentgenowskiego lub neutronowego) od płaszczyzn krystalograficznych określonego typu i zaznaczyć je na rzucie stereograficznym (Schulz 1949). Pomiar wykonujemy, używając monochromatycznego (filtrowanego) promieniowania za pomocą dyfraktometru wyposażonego w goniometr oraz przystawkę tekturową zwaną kołem Eulera (rys. 7, 8).
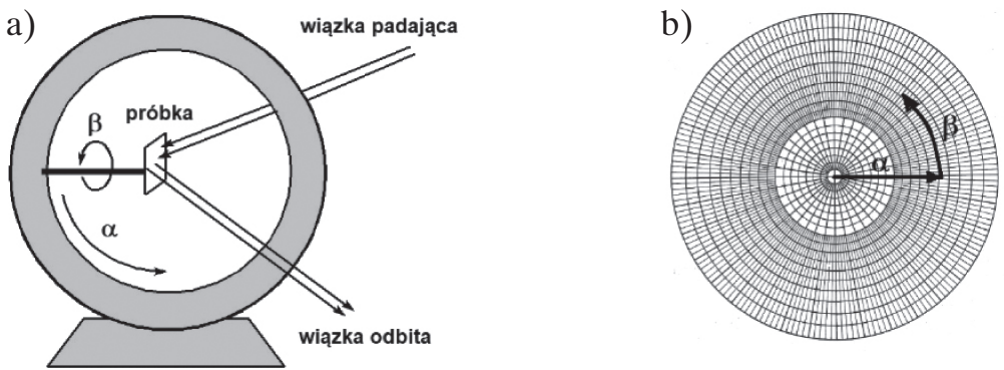

Rys. 7. Schemat budowy koła Eulera wraz z osiami obrotu odpowiadającymi kątom $\alpha$ i $\beta$ (a) oraz siatka biegunowa przedstawiająca zasadę nanoszenia wyników pomiarów tekstur na rzut stereograficzny (b)

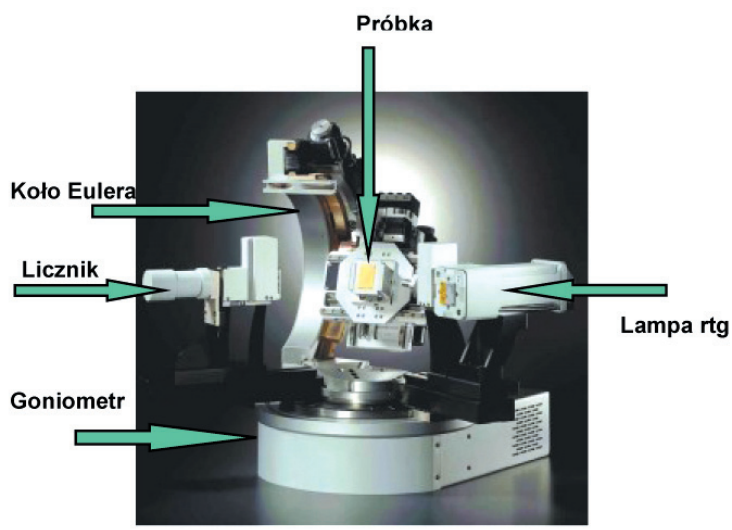

Rys. 8. Goniometr z kołem Eulera - stanowisko do pomiaru tekstur na dyfraktometrze Bruker D8 Advance 
Strategia pomiaru figury biegunowej jest następująca:

- Goniometr ustawiamy w położeniu $\Theta / 2 \Theta$ odpowiadającym warunkom dyfrakcji dla wybranej płaszczyzny krystalograficznej. Oznacza to, że dla tej płaszczyzny krystalograficznej spełnione ma być prawo Bragga $\left(n \lambda=2 d_{h k l} \sin \Theta\right)$.

- Wykorzystując koło Eulera umożliwiające obroty próbki, dokonujemy pomiarów intensywności promieniowania ugiętego na wybranej wcześniej płaszczyźnie krystalograficznej, zmieniając kąt $\alpha$ nachylenia próbki względem wiązki padające od $0^{\circ}$ do $90^{\circ}$.

- Dla każdego kąta $\alpha$ dokonujemy pomiarów, zmieniając kąt $\beta$ od $0^{\circ}$ do $360^{\circ}$ (obrót w wokół osi prostopadłej do próbki).

W praktyce pomiary wykonuje się dla kolejnych kątów $\alpha$ od $0^{\circ}$ do $70^{\circ}$ co $5^{\circ}$ i dla każdego kąta $\alpha$, zmieniając kąt $\beta$ od $0^{\circ}$ do $360^{\circ}$ co $5^{\circ}$. Taka strategia pomiarów prowadzi do pomiaru intensywności promieniowania na obwodzie 15 centrycznych kół na każdym po 71 punktów pomiarowych, co razem daje 1065 punktów pomiarowych. Taka sekwencja pomiarów pozwala na pomiar intensywności odbicia odpowiadających wszystkim punktom na rzucie stereograficznym leżącym w węzłach siatki biegunowej (rys. 7b) o odstępie między liniami równym $5^{\circ}$. Przypisując każdemu punktowi zmierzoną intensywność i zaznaczając ją na rzucie w odpowiednim miejscu, uzyskujemy tak zwaną figurę biegunową. Im więcej będzie płaszczyzn w danej orientacji, tym wyższą wartość zaznaczymy na rzucie.

W określony powyżej sposób metodą krokową wykonamy mapę rozkładu gęstości poszczególnych orientacji na powierzchni rzutu. Opisana procedura jest pomiarem krokowym. Inną możliwością jest pomiar ciągly, gdy w czasie pomiaru dyfrakcyjnego zarówno kąt $\alpha$, jak i kąt $\beta$ są w skorelowany sposób zmieniane $\mathrm{z}$ określoną prędkością W tym przypadku powierzchnia figury biegunowej jest przeskanowana pomiarem, którego miejsca leżą na spirali, której środek leży w środku figury biegunowej.

\subsection{Pomiary tekstur oparte na wyznaczaniu orientacji pojedynczych krystalitów}

Ponieważ obecnie istnieją metody wyznaczania lokalnych orientacji krystalograficznych bardzo małych obszarów $(0,5 \mu \mathrm{m})$, można wykonać serię pomiarów lokalnych orientacji na określonej powierzchni próbki i w ten sposób uzyskać obraz (mapę) orientacji występujących na tej powierzchni (Schwarzer 1993).

Lokalne pomiary orientacji wymagają zastosowania wiązek promieniowania o małych przekrojach lub techniki wyznaczania pojedynczych orientacji w mikroskopie skaningowym lub elektronowym. Przykładem techniki lokalnych pomiarów tekstury jest ich pomiar w mikroskopie elektronowym (skaningowym lub transmisyjnym) z wykorzysta- 
niem techniki EBSD (Electron Back Scattering Diffraction) opartej na akwizycji map orientacji zwanej Orientation Imaging Microscopy (OIM). Polega ona na wyznaczaniu orientacji krystalograficznych kolejnych punktów na powierzchni badanej próbki na podstawie obrazów dyfrakcyjnych elektronów wstecznie rozproszonych (Backscatter Kikuchi Pattern), a następnie przypisaniu im odpowiedniego koloru, co prowadzi do uzyskania obrazu mikroskopowego próbki widzianego przez kontrast „orientacji” krystalograficznej, czyli prowadzi do uzyskania mapy orientacji (Faryna 2012).

Pomiar techniką EBSD można zrealizować, wykorzystując zestaw aparaturowy przedstawiony na rysunku 9. Do uzyskania dyfrakcji konieczna jest zogniskowana wiązka elektronowa o stosunkowo dużej energii (np. $20 \mathrm{keV}$ ). Pada ona na próbkę nachyloną pod odpowiednim kątem $\left(20-30^{\circ}\right)$ do kierunku biegu tej wiązki. Efekty dyfrakcyjne (obrazy Kikuchiego) są uzyskiwane na ekranie fluorescencyjnym i rejestrowane w kamerze CCD. Zdygitalizowane obrazy są rejestrowane w komputerze, w którym za pomocą odpowiedniego oprogramowania wyznaczane są dla każdego z nich odpowiadające im orientacje krystalograficzne miejsca, z którego pochodzą. Każdemu obrazowi dyfrakcyjnemu jest przypisane położenie na próbce, z którego on pochodzi. Odpowiednie sterowniki kontrolują warunki pracy mikroskopu, położenie próbki (wiązki) i miejsce, z którego pochodzą obrazy dyfrakcyjne.

a)

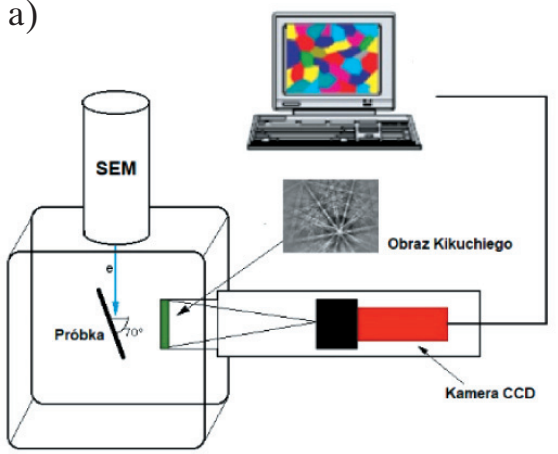

b)

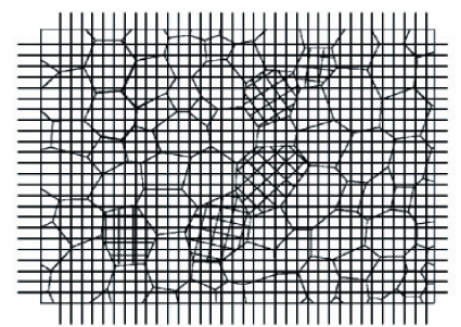

Rys. 9. Zestaw aparaturowy do pomiaru lokalnej tekstury metodą OIM w skaningowym mikroskopie elektronowym (a) oraz schemat pomiaru dwuwymiarowej mapy orientacji na powierzchni próbki (b)

Pomiar pojedynczych orientacji krystalograficznych w węzłach siatki pomiarowej na powierzchni próbki (rys. 9b) w skaningowym mikroskopie elektronowym (SEM) może być realizowany na dwa sposoby: przez przesuw wiązki elektronowej po powierzchni nieruchomej próbki (beam mode) oraz przez przesuw stolika goniometrycznego przy nieruchomej wiązce elektronowej (stage mode). Po przeskanowaniu całej powierzchni próbki uzyskuje się dla każdego węzła siatki pomiarowej obrazy dyfrakcyjne, a po ich rozwiązaniu informacje o orientacjach krystalograficznych tych miejsc. 
Przypisując każdej orientacji np. określony kolor, uzyskuje się obraz próbki widziany przez kontrast orientacji krystalograficznej, czyli dwuwymiarową mapę orientacji.

Zasada przypisywania kolorów poszczególnym orientacjom jest oparta na rzucie stereograficznym - określone kolory są przypisane poszczególnym orientacjom z trójkąta podstawowego na rzucie stereograficznym, co pokazano na rysunku $5 \mathrm{c}$.

Uzyskane techniką EBSD obrazy (mapy orientacji) przedstawiają lokalną teksturę materiału, gdyż pokazują, jakie orientacje występują w poszczególnych miejscach na powierzchni próbki. Zatem mapy orientacji przedstawiają teksturę nie w ujęciu statystycznym, ale ewidentnie lokalnym (miejscowym) i są doskonałą metodą badania niejednorodności tekstur np. w obszarach odkształconych albo we wczesnych etapach rekrystalizacji, gdy w odkształconej osnowie powstają nowe ziarna (zarodki) o innych orientacjach niż orientacja otaczającej osnowy. Przykłady dwuwymiarowych map orientacji uzyskanych metodą EBSD przedstawiono we wcześniejszym rozdziale na rysunku 5.

\section{Wpływ tekstury na własności materiałów}

Materiały steksturowane wykazują anizotropię własności. Ta anizotropia może być cechą pożądaną w pewnych wyrobach szczególnie wtedy, gdy zależy nam na ich kierunkowych własnościach. $\mathrm{Z}$ tego punktu widzenia tekstura materiału może być wykorzystywana do konkretnych zastosowań. Wymaga to oczywiście umiejętności jej świadomego kształtowania w procesach technologicznych produkcji konkretnych materiałów (Coulomb 1977).

Gdy pożądany jest wyrób anizotropowy (o jednakowych własnościach) w każdym kierunku, zasadniczo najlepszym rozwiązaniem jest stosowanie materiałów bez tekstury (niesteksturowanych), które są izotropowe. Często uzyskanie takiego wyrobu nie jest łatwe i wtedy można się posłużyć wyrobem pseudoizotropowym, czyli takim, który ma teksturę składającą się z kilku składowych, których wpływ na własności wzajemnie się kompensuje.

W związku z tym że zastosowanie wyrobu steksturowanego może być w konkretnych przypadkach rozwiązań konstrukcyjnych uzasadnione, poniżej przedstawiono wpływ tekstury na niektóre własności materiałów.

Własności mechaniczne, które zależą od tekstury, to: anizotropia normalna i anizotropia płaska, co wynika z wpływu tekstury na rozkład odkształceń i płynięcie plastyczne podczas kształtowania wyrobów. Istnieją metody wyznaczania współczynników anizotropii normalnej z figur biegunowych (Pańta i Chruściel 1984), a także wzory empiryczne określające zależność współczynników anizotropii normalnej od udziału różnego typu składowych w teksturze materiału (Blicharski 2004). Tylko odpowiednie typy 
tekstur w blachach zapewniają wysokie wartości współczynnika anizotropii normalnej i bliskie zeru wartości współczynnika anizotropii płaskiej, co oznacza podatność materiału do głębokiego tłoczenia. Przykładowo w stalach za korzystną składową tekstury blachy przeznaczonej do głębokiego tłoczenia uważa się składową $\{111\}<$ uvw>, natomiast składowe $\{001\}<110>$ i $\{110\}<001>$ są niepożądane. Występowanie w materiale anizotropii płaskiej spowodowanej teksturą przyczynia się do powstawania tak zwanych „uch” w procesie głębokiego tłoczenia, czyli nierównych krawędzi na wyrobach tłoczonych z blach. Od tekstury zależy również wytrzymałość na rozciąganie i wydłużenie mierzone w różnych kierunkach wyrobu, a także sprężystość, wytrzymałość na pełzanie i odporność na zmęczenie.

Własności magnetyczne metali ferromagnetycznych są silnie anizotropowe i dlatego tekstura ma wpływ na własności wyrobów stosowanych w elektrotechnice. Przykładem mogą być blachy elektrotechniczne stosowanych w budowie transformatorów. Blachy transformatorowe powinny mieć charakterystyczną teksturę zwaną teksturą Gossa $\{110\}<001>$, zapewniającą najmniejsze straty energetyczne (cieplne) w czasie pracy transformatora. Wynika to $\mathrm{z}$ tego, że orientacja krystalograficzna ziaren w blachach wpływa istotnie na wartość ich stratności oraz przenikalności magnetycznej. Również ze względu na zależności własności magnetycznych od orientacji ziaren większość stosowanych obecnie magnesów trwałych ze stopów żelazo-aluminium-nikiel-kobalt (alnico) produkowana jest w warunkach kontrolowanej krystalizacji w polu magnetycznym w celu uzyskania pożądanej tekstury. Powolne studzenie tych stopów w polu magnetycznym wzmacnia ich teksturę i dodatkowo poprawia moc właściwą magnesów w kierunku działania tego pola.

Od orientacji krystalograficznej zależy praca wyjścia elektronu, a zatem od tekstury zależy przebieg procesu emisji termoelektronowej. Tekstura ma wpływ również na takie własności materiałów i procesy z nimi związane jak korozja i trawienie. Przez kształtowanie tekstury uzyskuje się efekt umocnienia teksturowego metali o sieci heksagonalnej. Tekstura ujawnia swoją obecność i wpływa na własności eutektyk ukierunkowanych. Steksturownie prętów uranowych ma również wypływ na ich własności.

\section{Podsumowanie}

Ponieważ większość inżynierskich materiałów polikrystalicznych jest steksturowana, planując ich badania, należy uwzględnić pomiar tekstury, a w ramach analizy wyników jej wpływ na mierzone własności. Również projektując technologie produkcji materiałów, koniecznie powinno się uwzględnić wpływ procesów produkcyjnych (odlewania, deformacji, obróbki cieplnej itd.) na tworzenie się tekstury w gotowym wyrobie, gdyż tekstura może znacząco wpłynąć na własności wyrobu, a szczególnie jego anizotropię. 


\section{Literatura}

Blicharski M., 2002, Odksztatcenie i pękanie, Wydawnictwa AGH, Kraków.

Blicharski M., 2004, Inżynieria materiałowa - stal, Wydawnictwa Naukowo-Techniczne, Warszawa.

Bojarski Z., Łągiewka E., 1988, Rentgenowska analiza strukturalna, Państwowe Wydawnictwo Naukowe, Warszawa.

Bonarski J.T., 2001, Rentgenowska tomografia teksturowa, PAN Instytut Metalurgii i Inżynierii Materiałowej, Kraków.

Bunge H.J., 1969, Mathematische Methoden der Textureanalyse, Akademie-Verlag, Berlin.

Bunsch A., Juul Jensen D., 1992, Recrystallization and texture transformation kinetics in isothermally annealed cold rolled copper, Archives of Metallurgy, vol. 37, s. 157-173.

Coryell S.P., Findley K. Mataya M.C., 2010, Flow behavior of Superalloy 945 during high temperature deformation, [w:] TMS 2010 Supplemental Proceedings, Vol. 1, Seattle, WA, s. 291-298.

Coulomb P., 1977, Tekstury w metalach o sieci regularnej, Państwowe Wydawnictwo Naukowe, Warszawa.

Cullity B.D., Stack S.R., 2001, Elements of X-Ray Diffraction, Prentice Hall, Upper Saddle River.

Dobrzański F., 2008, Stereologiczna analiza tekstury $w$ badaniach strukturalnych, Uczelniane Wydawnictwa Naukowo-Dydaktyczne AGH, Kraków.

Faryna M., 2012, Dyfrakcja elektronów wstecznie rozproszonych w skaningowym mikroskopie elektronowym, Wydawnictwa AGH, Kraków.

Hansen J., Pospiech J., Lücke K., 1978, Tables for Texture Analysis of Cubic Crystals, Springer-Verlag Berlin Heidelberg.

Jura J., 1993, Zastosowanie funkcji modelowych w ilościowej analizie tekstur metali o sieci regularnej, Zeszyty Naukowe Akademii Górniczo-Hutniczej im. Stanisława Staszica. Metalurgia i Odlewnictwo, z. 148, Akademia Górniczo-Hutnicza, Kraków.

Juul Jensen D., 2000, Three-Dimensional Orientation Imaging, [w:] Schwarz A.J., Kumar M., Adams B.L. (eds.), Electron Backscatter Diffraction in Materials Science, Springer, s. 91-104.

Karp J., 1968, Tekstury walcowania bliźniaków w aluminium, Zeszyty Naukowe Akademii Górniczo-Hutniczej im. Stanisława Staszica. Metalurgia i Odlewnictwo, z. 27, Akademia Górniczo-Hutnicza, Kraków.

Kelly A., Groves G.W., 1980, Krystalografia i defekty kryształów, Państwowe Wydawnictwo Naukowe, Warszawa.

Major B., 1987, Rola ścinania $w$ procesie tworzenia się tekstur $w$ metalach i stopach o sieci A1, Zeszyty Naukowe Akademii Górniczo-Hutniczej im. Stanisława Staszica. Metalurgia i Odlewnictwo, z. 112, Wydawnictwa AGH, Kraków. 
Pańta A., Chruściel K., 1984, Określanie w oparciu o zwykłe figury biegunowe, wspótczynników anizotropii normalnej $R(a)$ i wspótczynnika średniej anizotropii normalnej dla blach karoseryjnych, Archiwum Hutnictwa, t. 29, z 2, s. 297-310.

Ratuszek W., 1995, Tekstury odksztatcenia i rekrystalizacji w stopach na osnowie miedzi, Rozprawy, Monografie - Akademia Górniczo-Hutnicza im. Stanisława Staszica, 27, Wydawnictwa AGH, Kraków.

Schultz L.G., 1949, A Direct Method of Determining Preferred Orientation of a Flat Reflection Sample Using a Geiger Counter of X-Ray Spectrometer, Journal of Applied Physics, vol. 20, s. 1030-1033. https://doi.org/10.1063/1.1698268.

Schwarzer R.A., 1993, The determination of local texture by electron diffraction - A tutorial review, Textures and Microstructures, vol. 20, s. 7-27. https://doi.org/10.1155/TSM.20.7.

Schwarzer R.A., 2005, Advances in the analysis of texture and microstructure, Archives of Metallurgy and Materials, vol. 50, s. 7-20.

Skrzypek S.J., Ratuszek W., Bunsch A., Witkowska M., Kowalska J., Goły M., Chruściel K., 2010, Crystallographic texture and anisotropy of electrolytic deposited copper coating analysis, Journal of Achievements in Materials and Manufacturing Engineering, vol. 43, nr 1, s. 264-268.

Truszkowski W., Król J., Major B., 1980, Inhomogeneity of rolling texture in fcc metals, Metallurgical Transaction, vol. 11A, s. 749-758. https://doi.org/10.1007/BF02661204. Wassermann G., Grewen J, 1962, Texturen metallischer Werkstoffe, Springer-Verlag Berlin Heidelberg.

Wierzbanowski K., Materiały pomocnicze z Rzeczywistej Struktury Materiałów, http:// www.ftj.agh.edu.pl/ wierzbanowski/Rsm.htm [dostęp: 25.07.2019]. 